\title{
IMPACT OF CORPORATE GOVERNANCE PRACTICES ON CORPORATE SOCIAL RESPONSIBILITY: EVIDENCE FROM LISTED BANKS, FINANCE AND INSURANCE COMPANIES IN SRI LANKA
}

\author{
Lingesiya Kengatharan and Thangarasa Sivakaran \\ Department of Financial Management, \\ University of Jaffna, Sri Lanka \\ Email: lingesiya@univ.jfn.ac.lk
}

\begin{abstract}
The objective of this study is to examine the impact of corporate governance practices on corporate social responsibility of the listed banks, finance and insurance companies in Sri Lanka over the period of 2013 to 2017. A sample of 20 firms out of 72 banks, finance and insurance firms listed on the Colombo Stock Exchange was considered for this study. The study utilized secondary data which were collected from annual reports of the sampled firm. Corporate social responsibility was measured by a 40 -item disclose index. Corporate governance practices were measured by board size, board independence, women on board and size of audit committee. Return on assets and firm size were considered as control variables. Results of the study revealed that independent directors, return on assets and firm size have significantly positively influenced corporate social responsibility. Board size, women on the board and size of audit committee have not shown any significant impact on corporate social responsibility. The result of this study is deemed to benefit external investors and shareholders who will be able to know that how the firm committed their Corporate Social Responsible activities rather than profit maximization. Further the finding is useful for interested people such as public, government, and other financial institutions. Moreover, it will help to future researchers for further investigation related to this topic.
\end{abstract}

Keywords: corporate social responsibility, corporate governance practices, stakeholder theory

ARTICLE INFO

Article History:

Received: 23 February 2019

Accepted: 23 July 2019

Published: 31 August 2019 


\section{INTRODUCTION}

A significant part of the finance process involves finance managers seeking answers to three critical decisions namely financing decision, investment decision and dividend decision (Baker \& Wurgler, 2004). In recent decades irresponsible behavior by unscrupulous managers has increased the importance of Corporate Governance (CG), ethics, trust and accountability. Based on this Corporate Social Responsibility (CSR) has become formal or informal set of the organization.

CSR refers to finding a balance between the financial and non-financial goals of corporations, while acting in the best interest of society as a whole (Kiliç, Kuzey \& Uyar, 2015). Typical CSR activities and programs include the preservation of environmental capital by means of reducing waste, leveraging reverse supply chains and restraining carbon emissions and the delivery of social improvements including advanced employee training, safer working environments and contributions to communities (McWilliams \& Siegel, 2000; Shen \& Benson, 2014). A focus on CSR moves firm attention away from a purely profit maximizing objective in the exclusive interest of shareholders to one that considers the interests of a broader set of stakeholders (Barnett, 2007).

The meaning of the term corporate governance is a subject of considerable debate. The concept has been defined in many ways. The Organization for Economic Co-operation and Development (OECD) has defined corporate governance as, "procedures and processes according to which an organization is directed and controlled. The CG structure specifies the distribution of rights and responsibilities among the different participants in the organization - such as the board, managers, shareholders and other stakeholders - and lays down the rules and procedures for decision-making." The Institute of Chartered Accountants of Sri Lanka is proud to be the pioneer in introducing CG to Sri Lanka. The first Code, Code of Best Practice on matters related to financial aspects of CG, was issued in December 1997. The updated code was issued in March 2003 as the Code of Best Practice on CG. In June 2008 a revised Code of Best Practice on CG was issued. This project was a joint initiative between the Securities \& Exchange Commission of Sri Lanka and the Institute of Chartered Accountants of Sri Lanka. The current revision once again a joint 
initiative between the Securities \& Exchange Commission of Sri Lanka and the Institute of Chartered Accountants of Sri Lanka was commenced in the final quarter of 2011.

Currently business organizations are giving much attention on CG and CSR as firms not only want to concentrate just on generating profit returns for shareholders but also asked to take responsibilities for firm's other stakeholders: customers, suppliers, creditors, civil societies, employees etc., from Social, Environment and Economic Perspective. Accordingly, nowadays most of the firms aim to have a healthier CSR performance with better CG to maintain corporate sustainability in the business world. Relationship between CG and CSR are considered as two sides of the same coin (Bhimani \& Soonawalla, 2005) as both CSR and CG motivate firms to perform their role towards the goodness of society. Companies which are making contribution towards economic growth have been thought responsible for creating social problems in areas like safety and health, waste management, environmental pro-activeness, product quality and resource depletion. Due to the problems of considering profit as the ultimate indicator to compute company's performance, in 1970s some accountancy institutions included CSR disclosures in annual reports of company. Most of the research work has been carried out in developed countries and over the years, the relationship between CG and CSR activities has been examined by several researchers and their opinions have been expressed in different points of views during those studies. Therefore, conclusions are still in different views. In Sri Lanka, few research studies carried out related to sustainability reporting by publicly listed companies in Sri Lanka and some are working determinants of sustainability reporting in developing countries in the case of Sri Lanka. But, to the best of our knowledge, there are very few studies that directly focus to evaluate the impact of corporate governance practices on corporate social responsibility in listed banking finance and insurance companies in Sri Lanka. Thus this study intends to fill this research gap. In this research study, the researcher aims to analyze the listed banking finance and insurance companies in Colombo Stock Exchange (CSE) in Sri Lanka. According to the World Bank Report in 2017, the banking, insurance and finance industry is a significant sector that plays a major role in the Sri Lankan economy. Today's banking business environment is too competitive and dynamic where challenges are updated day by day because of advanced development in the technology, fully fledged 
globalization. In order to tackle these new challenges, firms should build good bond economically, environmentally and socially. Therefore, most of the companies engage with CSR activities and try to build their corporate image through the disclosure of those activities in annual reports and other publications. Governance of Banking, insurance and finance companies are giving much consideration on CSR activities in order to sustain and survive the customers in the competitive world. Therefore, this study attempts to examine the relationship between corporate governance practices and CSR activities of Banking, Insurance and Finance companies in Sri Lanka

\section{LITERATURE REVIEW}

\section{Theories Related to CSR Reporting}

\section{Legitimacy theory}

Legitimacy theory is a corollary of the business ethics theory: whereas business ethics stresses the need for firms to be morally responsible to their host communities, it accords recognition to those firms that fulfill their ethical responsibilities to the society. Hence, it is a key concept in the conceptualization of CSR (Palazzo \& Scherer, 2006). This theory is widely used in the literature to explain CSR reporting practices. This theory argues that an organization is legitimized when its value system matches that of the social system of which it forms a part and that where there is a mismatch, the organization's legitimacy is threatened (Lindblom, 1994). Embraced by many researchers, the theory suggests that the corporate motivation to disclose social and environmental information is to meet the norms and bounds of societal expectations (Deegan, 2002). The theory looks at the "society" within which an organization operates. There are many groups of individuals within that society, such as shareholders, creditors, employees, customers and suppliers, who may be interested in the organization's social and environmental activities. These groups have been identified by Freeman (1984) as "stakeholders" who may affect or be affected in the process of the achievement of the organization's objectives. 


\section{Stakeholder theory}

The Stakeholder theory posits that the long-term survival and success of the corporation requires the support of its stakeholders (van der Laan, Adhikari, \& Tondkar, 2005). Stakeholders include creditors, employees, customers, suppliers, auditors, regulators and government, as well as the general public. These stakeholders have expectations regarding CSR activities of the entities, such as prevention of pollution, effective and efficient utilization of natural resources, work force diversity, employment of minorities, elimination of discrimination, etc. (Adebayo, 2000). Entities should act in accordance with the expectations of stakeholders to gain their support by using CSR as a communication channel (Barako \& Brown, 2008) and by disclosing the environmental and social information that they demand (Freedman \& Jaggi, 2005). For instance, companies should satisfy their consumers and employees economically without damaging the environment, depleting natural resources or subjecting their employees to dehumanizing working conditions (Achua, 2008), disclosing those accomplishments via several channels, including annual reports.

\section{Corporate Governance Practices}

\section{Board size}

Board size refers to the number of directors as members on the board. Larger boards are viewed as being more desirable as they can provide firms with more ways to connect with external stakeholders controlling resources necessary to firms 'operations (Abeysekera, 2010). Moreover, larger boards are more likely to include directors with greater diversity in education and industry experience and this diversity allows board members to provide the management with high-quality advice (Zahra \& Pearce, 1989). This could then contribute to the firm's image and relationships with stakeholders. Muktar, Mohammad, Jibril and Muhammad (2016) examined the effects of CG on CSR disclosure of firms in the Nigerian food products industry for the period of 2008-2012. The results of the study revealed that there was a significant positive relationship between board size and CSR disclosure. CEO Duality did not show any significant relationship with CSR disclosure. However, there was a significant negative relationship of board composition, and audit committee composition with CSR disclosure of the sampled firms. Therefore, the current study hypothesized that: 
$\mathbf{H}_{1}$ a: Board Size has a significant impact on CSR

\section{Women on board}

Basically there is a perception among the people that if there is a larger number of female representatives, there will be lower performance (Adams \& Ferrera, 2009). Therefore, research that has included the variable of female representatives has been carried out. According to Carter et al. (2003) a higher proportion of female directors at the board associates with better performance. Campbell and Minquezvera (2008) have found that there is a significant positive relationship between proportion of female directors on the board and firm performance. However, there are some other researchers have found that there is a negative effect of higher proportion of female directors in the board (Adams \& Ferreira, 2009; Ahern \& Dittmar, 2012). One considerably debated characteristic of board diversity is gender (Rao et al., 2012). Female on the Board is calculated by the number female directors on board (Arcay \& Vazquez, 2005). Khan (2010) carried out a study to evaluate the impact of CG elements on CSR reporting focusing private commercial banks of Bangladesh. The outcome of the study revealed that the non-executive directors and foreign ownership are significantly influenced on CSR reporting whereas women representation on the board did not show any significant relationship with CSR reporting. The present study tries to examine the impact of women on board on CSR activities. Therefore, the following hypothesis was formulated

\section{$\mathbf{H}_{1} \mathbf{b}$ : Women on the Board has a significant impact on CSR}

\section{Size of audit committee}

The Resource dependency theory argues that larger audit committees are willing to devote greater resources and authority to effectively carry out their responsibilities (Allegrini \& Greco, 2011). More directors on committees are more likely to bring diversity of views, expertise, experiences and skills to ensure effective monitoring (Bedard \& Gendron, 2010). Hence, a higher number of audit committee members is likely to help such committee to uncover and resolve potential issues in corporate reporting process (Li et al., 2012). Persons (2009) has found empirical evidence that many directors on an audit committee appear to enhance the level of voluntary disclosure. Said, Zainuddin, and Haron (2009) conducted a study to examine the relationship between CG components and CSR in 
Malaysian public listed companies. Board size, independent non-executive directors, CEO duality, audit committee, managerial ownership, foreign ownership, and government shareholding are considered as corporate governance components. From these corporate governance components, government ownership and audit committees are significantly and positively related to corporate social responsibility. Fallah and Mojarrad (2019) investigated the relationship between CG and CSR disclosure in a sample of 64 companies listed on the Tehran Stock Exchange. The outcome of the study expressed that, audit committee composition, board tenure and ownership concentration have significant and positive influence on CSR disclosure level. Therefore, the controversial results are presented in the literature. Thus, the following hypothesis was formulated to evaluate the impact of size of audit committee on CSR activities

$\mathbf{H}_{1} \mathbf{c}$ : Audit committee Size has significant impact on CSR

\section{Board independence}

The effectiveness of corporate governance in reducing agency problems between management and shareholders depends significantly on the composition of the board of directors (Fama \& Jensen, 1983). According to the code of best practice on corporate governance 2013, the board should include Non-Executive Directors of sufficient caliber and number for their views to carry significant weight in the board's decisions. The board should include at least two Non-Executive Directors or such number of Non-Executive Directors equivalent to one third of total number of Directors, whichever is higher. Empirical evidence of the effect of independent directors is mixed. Eng and Mak (2003) found a significant negative association between board independence and disclosure levels. Similar results were obtained by Gul and Leung (2004) and Huafang and Jianguo (2007). In contrast, Ho and Wong (2001) found no association between the number of outside non-executive directors and the level of disclosure. It is hypothesized that

$\mathbf{H}_{1} \mathbf{d}$ : Independent directors have a significant impact on CSR. 


\section{Control Variables}

\section{Return on assets (ROA)}

Socially responsible firms can be anticipated to be highly profitable as these firms have the key success factors. Haniffa and Cooke (2005) and Said et al. (2009) disclose a considerable and constructive association between profitability and the levels of CS reporting. They argue that profitable firms disclose CSR information to portray their role in the welfare of the community and validate their survival. Continuing these studies recently, the findings of Ehsan and Kaleem (2012) about the nature of association between CSR and firm performance suggest a positive relationship.

\section{Firm size (FS)}

The control variable for this research is firm size. Large firms are supposed to have more activities and a greater impact on society. It is a fact that big firms have more shareholders who may have concern about social programs undertaken by the firm (Said et al., 2009; Cowen, Ferreri, \& Parker, 1987; Nazli \& Ghazali, 2007). Based on the outcomes of these previous studies, a constructive relation is anticipated between company size measured in terms of sales (Arora \& Dharwadkar, 2011) and CSR disclosure. Said, Zainuddin and Haron (2009) found that there was a positive relationship between firm size and CSRD.

\section{METHODOLOGY}

Having understood the relationship between CG and CSR from the literature, the following conceptual framework was developed to examine the impact of CG practices on CSR activities: 


\section{Conceptual Framework}

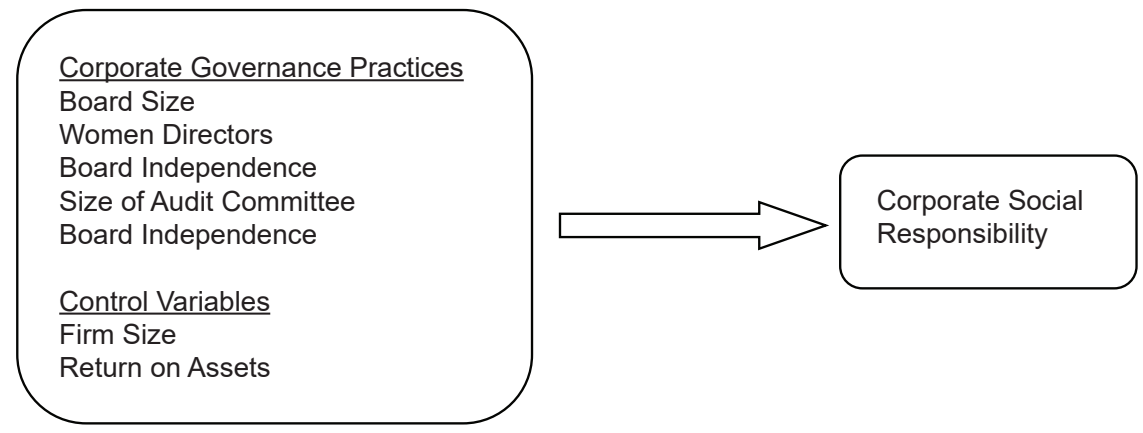

Table 1: Operationalization of the Variables

\begin{tabular}{|c|c|c|c|}
\hline Concept & Variable & Indicator & Measurement \\
\hline \multirow{4}{*}{$\begin{array}{l}\text { Independent } \\
\text { variable } \\
\text { Corporate } \\
\text { governance } \\
\text { practices }\end{array}$} & Board Size & $\begin{array}{l}\text { Number of board } \\
\text { members }\end{array}$ & $\begin{array}{l}\text { Number of inside and outside } \\
\text { directors on the board } \\
\text { (Rahman \& Muhamad, 2013) }\end{array}$ \\
\hline & $\begin{array}{l}\text { Women } \\
\text { irectors }\end{array}$ & $\begin{array}{l}\text { Number of females } \\
\text { directors }\end{array}$ & $\begin{array}{l}\text { Number of Women on the Board } \\
\text { Total Directors on the Board } \\
\text { (Khan, 2010) }\end{array}$ \\
\hline & $\begin{array}{l}\text { Audit } \\
\text { Committee } \\
\text { size }\end{array}$ & $\begin{array}{l}\text { Number of audit } \\
\text { members }\end{array}$ & $\begin{array}{l}\text { Number of members in the audit } \\
\text { committee } \\
\text { (Norwal \& Jindal, 2017) }\end{array}$ \\
\hline & $\begin{array}{l}\text { Board } \\
\text { Independent }\end{array}$ & $\begin{array}{l}\text { Number of } \\
\text { independent } \\
\text { directors }\end{array}$ & $\begin{array}{l}\text { Number of independent directors } \\
\text { Total board of directors } \\
\text { (Sheikh \& Khan, 2015) }\end{array}$ \\
\hline $\begin{array}{l}\text { Dependent } \\
\text { variable } \\
\text { Corporate } \\
\text { social } \\
\text { responsibility }\end{array}$ & SR index & $\begin{array}{l}\text { Percentage } \\
\text { of Economic, } \\
\text { Society, Social \& } \\
\text { Environment Items } \\
\text { disclosed }\end{array}$ & $\begin{array}{l}\text { EActual Items Disclosed } \\
\text { Maximum Checklist Items } \\
\text { (Habbash, 2016; Elzahar \& } \\
\text { Hussainey, 2012) }\end{array}$ \\
\hline \multirow[t]{2}{*}{$\begin{array}{l}\text { Controlling } \\
\text { variable }\end{array}$} & Firms size & Total assets & $\begin{array}{l}\text { Natural logarithm of total asset } \\
\text { (Wai, 2013) }\end{array}$ \\
\hline & $\begin{array}{l}\text { Return on } \\
\text { Assets }\end{array}$ & $\begin{array}{l}\text { Ratio of return to } \\
\text { total asset }\end{array}$ & $\frac{\text { Net Income }}{\text { Total Assets }} \times 100$ \\
\hline
\end{tabular}

\section{CSR Index}

Thematic content analysis (Krippendorf, 1980) was used to measure corporate social responsibility disclosure (CSRD). As with Gray et al. (1995), Haniffa and Cooke (2005), and Dias et al. (2016), constructed an inclusive CSRD checklist. This comprised three CSR dimensions and 40 
individual CSR indicators (5 economic, 20 social, 15 environmental) that allow a broad view of a company's CSRD.

Choice of the 40 indicators was influenced by the world's most widely used standards on CSRD, the GRI Guidelines (Larrinaga et al., 2008). They focused especially on the GRI core indicators that represent well established CSR indicators (Dias et al., 2016). The selected items were adapted to avoid penalizing companies that did not use the GRI model. Each item scored 1 if disclosed and zero if not.

The scores for each item were then added to derive a final score for each company. The approach to scoring is additive and equally weighted (Haniffa \& Cooke, 2005). The final CSRD index was calculated as follows:

$$
\sum_{j=1}^{e} e j / e
$$

Where

ej = Attribute analysis ( 1 if disclosure item is found, and 0 if not found)

$\mathrm{e}=$ Maximum number of items a company can disclose (40)

The extent of CSR disclosure is the model's dependent variable. To measure its extent, this study followed four steps derived from previous studies (Botosan, 1997; Rizk et al., 2008; Said et al., 2009; AbuRaya, 2012). First, this study prepared a checklist comprises 17 disclosure items of CSR based on ISO 26000. ISO 26000 is an international standard issued by ISO and provides guidelines on social responsibility for all public and private firms. It is noteworthy that the number of checklist items differs among studies; Rizk et al. (2008) state that the checklist items range from 17 to 224 items. Second, this study applied manual content analysis to analyse the sample firms' annual reports and identify the actual CSR disclosure items compared to the checklist. Third, this study followed the dichotomous scoring procedure by assigning one if the item is disclosed and zero otherwise. Fourth, this study sums the total number of items actually disclosed for each annual report and divide this number by the maximum number of the checklist items to get the ratio of CSR disclosure by applying the following equation: 
In this study, researchers conclude $40 \mathrm{CSR}$ activities which are complied from previous studies. GRI guidelines are adopted mostly in Sri Lankan banks, finance and insurance firms. Generally, the banks, finance and insurance firms provide 40 to 50 disclosures on their annual reports. In this regard the researchers averagely selected 40 CSR activities checklists based on the bank of Hatton National Bank because they are a bank that provided more CSR disclosure.

\section{Data Collection}

The Colombo Stock Exchange (CSE) has 299 companies representing 20 business sectors as at $29^{\text {th }}$ March 2018, with a Market Capitalization of Rs.3, 032.7Billion (www.cse.lk). Selected for the present study population is 72 companies listed in CSE under Bank, finance and insurance sector. The sample of the current study included only 10 banks, 7 finance companies and 3 insurance company listed under this sector due to the availability of data. Data was collected from secondary sources, such as annual reports and corporate social responsibility disclosures of selected companies on CSE for the period 2013 to 2017.

\section{Model Specification}

$$
\mathrm{CSR}=\beta 0+\beta 1 \mathrm{BS}+\beta 2 \mathrm{WOB}+\beta 3 \mathrm{SAC}+\beta 4 \mathrm{BI}+\beta 6 \mathrm{FS}+\beta 7 \mathrm{ROA}+\varepsilon
$$

Where,

$\begin{array}{lll}\text { CSR } & - & \text { Corporate Social responsibility } \\ \text { BS } & - & \text { Board Size } \\ \text { WOB } & - & \text { Women Directors } \\ \text { SAC } & - & \text { Size of Audit Committee } \\ \text { BI } & - & \text { Board Independence } \\ \text { FS } & - & \text { Firm Size } \\ \text { ROA } & - & \text { Return on Assets } \\ \varepsilon & - & \text { Error term } \\ \beta_{0}, \beta_{1}, \beta_{2,} \beta_{3}, \beta_{4}, \beta_{5,}, \beta_{6}, \beta_{7} \text { Model coefficients }\end{array}$


DATA PRESENTATION AND ANALYSIS

Table 2: Descriptive Statistics of the Variables

\begin{tabular}{lccccc}
\hline \multicolumn{1}{c}{ Variable } & Obs & Mean & Std. Dev. & Min & Max \\
\hline BS & 100 & 9.8300 & 2.4373 & 5 & 15 \\
\hline ID & 100 & 0.3914 & 0.1589 & 0.1428 & 0.8889 \\
\hline WOB & 100 & 0.1646 & 0.1122 & 0.0000 & 0.4444 \\
\hline SAC & 100 & 4.6700 & 1.8480 & 1 & 11 \\
\hline ROA & 100 & 3.0297 & 4.4896 & -1.9390 & 36.6335 \\
\hline FS & 100 & 10.8235 & 0.6527 & 9.6043 & 12.0582 \\
\hline CSRR & 100 & 0.6278 & 0.1518 & 0.2500 & 1.0000 \\
\hline
\end{tabular}

Source: Survey data

Table 2, illustrates the descriptive statistics for the $\mathrm{CG}$ practices proxies namely BS, ID, WOB, SAC and control variable such as ROA and FS and CSRD as dependent variable.

The data containing 100 observations were collected from the annual financial reports of the respective firms. The mean of the CSR disclosure index for the entire sample is 0.6278 with the standard deviation of 0.1518 and the CSRR range is 0.25 to 1.00 .

Board size varies between 5 and 15 persons, averaging 9.83 with the Standard Deviation of 2.4373 which means that some companies have relatively large board sizes, while others have relatively small board sizes. The size of the Independent Directors varies widely across the sample firms as the minimum and the maximum is $14.28 \%$ and $88.89 \%$ members respectively, the mean proportion of ID $39.14 \%$. Women on board show a mean of $16.46 \%$ with a standard deviation of 0.1122 and a minimum value of $0.00 \%$ and maximum of $44.44 \%$.

The results show that size of audit committee ranges from one to eleven members with a mean of approximately five members. In terms of control variables, the mean size of the firm is 10.8235 the respective standard deviation of 0.6527 with the range of minimum 9.6043 to maximum 12.0583. Another control variable ROA average was reported that $3.0297 \%$, which was ranged from $-1.9390 \%$ to $36.6335 \%$. 


\section{Correlation Analysis}

Table 3: Correlation Matrix

\begin{tabular}{|c|c|c|c|c|c|c|c|}
\hline & BS & ID & WOB & SAC & ROA & FS & CSR \\
\hline BS & 1.0000 & & & & & & \\
\hline ID & -0.0549 & 1.0000 & & & & & \\
\hline WOB & 0.1401 & 0.0716 & 1.0000 & & & & \\
\hline ACS & 0.2924 & 0.2867 & 0.3093 & 1.0000 & & & \\
\hline ROA & -0.1501 & -0.0899 & -0.2432 & -0.2669 & 1.0000 & & \\
\hline FS & 0.1563 & 0.0774 & 0.5073 & 0.4471 & -0.3490 & 1.0000 & \\
\hline CSRR & $0.2312^{* *}$ & $0.2222^{* *}$ & $0.3073^{* * *}$ & $0.4028^{* * *}$ & -0.0909 & $0.6184^{\star * *}$ & 1.0000 \\
\hline
\end{tabular}

Source: Survey data

As shown in Table 3, board size is significantly positively associated with CSR reporting of the listed banking finance and insurance firms in Sri Lanka $(r=0.2312, p<0.05)$. It shows that an increase in the number of members on board pave the ways to increase the CSR reporting levels of banks, finance and insurance companies. Prior researchers have indicated that board size has a positive relation on CSR reporting (Siregar \& Bachtiar, 2010; Kiliç et al., 2015; António et al., 2017, Sadia et al., 2015). Therefore, results of the study is consistent with the previous studies.

Correlation value between board independence and CSR reporting is significantly positively associated $(r=0.2222, p<0.05)$. Socially responsible companies tend to have boards with more outsider directors (Webb, 2004). Ideally, independent non-executive directors monitor the activities of executive directors. They are claimed to have a strong concern for the reputation of the company and its CSR programs (Zahra \& Stanton, 1988).

There is a positive correlation between board diversity (women on board) and CSR reporting which is significant at the 0.01 level $(r=0.3073$, $p<0.01$ ). Adams and Ferreira (2009) found that the existence of female directors on the board will increase the quality of decisions and may affect 
the solution of complicated issues such as CSR activities or disclosures, as with this findings of the study consistent with the Adams and Ferreira.

Significant positive connotation has been shown between the size of the audit committee and CSR reporting $(r=0.4028, p<0.01)$. The Resource Dependency Theory argues that larger ACs are willing to devote greater resources and authority to effectively carry out their responsibilities (Allegrini \& Greco, 2011).

ROA has a statistically insignificant relationship with CSRR $(r=$ $-0.0909, p>0.05$ ). Findings of this study is consistent with Mutuku (2004) who found that there is no significant association between CSR and ROA. Firm size is often considered to be significantly and positively $(r=0.6184$, $p<0.01)$ associated with company disclosure and this result is consistent with Muttakin et al. (2015).

Table 4: Results of Multi-Collinearity

\begin{tabular}{lcc}
\hline \multicolumn{1}{c}{ Variables } & \multicolumn{2}{c}{ Collinearity statistics } \\
\hline BS & VIF (1 to 10$)$ & Tolerance $(\mathbf{0}$ to $\mathbf{1})$ \\
\hline ID & 1.13 & 0.617023 \\
\hline WOB & 1.12 & 0.892213 \\
\hline ACS & 1.37 & 0.729321 \\
\hline ROA & 1.50 & 0.667381 \\
\hline FS & 1.17 & 0.853024 \\
\hline
\end{tabular}

Source: survey data

The VIF for all independent variables and control variables are at the acceptable levels (between 1.12 and 1.62), well below the threshold VIF value of 10 (Kennedy, 1998; Haniffa \& Cooke, 2005) indicating the absense of multi-collinearity. 
Table 5: Regression Analysis

\begin{tabular}{|c|c|c|c|c|c|c|}
\hline Number of obs & & & & & & 100 \\
\hline$F(6,93)$ & & & & & & 13.57 \\
\hline Prob $>f$ & & & & & & 0.0000 \\
\hline $\mathrm{R}$ - squared & & & & & & 0.4669 \\
\hline Adj R-squared & & & & & & 0.4325 \\
\hline Root MSE & & & & & & 0.1143 \\
\hline CSR & Coef. & Std. Err. & $\mathrm{t}$ & $P>t$ & $\begin{array}{c}\text { [95\% } \\
\text { Conf. }\end{array}$ & Interval] \\
\hline BS & .0093 & .0050 & & 0.067 & -.0006 & .0192 \\
\hline & & & 1.85 & & & \\
\hline ID & .1672 & .0765 & 2.18 & 0.031 & .0151 & .3193 \\
\hline WOB & -.0301 & .1199 & -0.25 & 0.802 & -.2683 & .2080 \\
\hline ACS & .0072 & .0076 & 0.96 & 0.341 & -.0078 & .0224 \\
\hline ROA & .0061 & .0027 & 2.20 & 0.030 & .0006 & .0116 \\
\hline FS & .1433 & .0224 & 6.39 & 0.000 & .0988 & .1878 \\
\hline _cons & -1.1280 & .2362 & -4.77 & 0.000 & -1.5971 & -.6588 \\
\hline
\end{tabular}

The results of OLS indicated in Table 4 shows that the coefficient of determination $R^{2}$ shows 0.4325 indicating that the variables considered in the model account for about 43.25 percentage change in the dependent variable that is CSR disclosure, while the remaining of the change 56.75 percentage is as a result of other variables not addressed by this model. It denotes that 43.25 percentage of total variation in CSR reporting of Sri Lankan banking finance and insurance firms is caused by their board size, board independence, women who serve on the board, size of audit committee, ROA and the size of the firms. This indicates that the model is fit $(F=13.57, p<0.01)$ and that the explanatory variables are properly selected, combined and used as the substantial value of the reporting quality is accounted for by the explanatory variables. Hence, the findings of the study can be relied upon.

The model was evaluated based on the OLS regression result in Table 4. The result shows that the relationship between CSR disclosure and BS is positive but statistically it's not significant $(\mathrm{t}=1.85$ and $\mathrm{p}>0.05)$ because of the coefficient is very low (coef $=0.0093$ ). 
The relationship between ID and CSR reporting is positive and significant, this can be justified through the positive $(t=2.18$ and $\mathrm{p}<0.05)$. It has also been confirmed by the positive coefficient of 0.1672 , which means that an increase in ID will increase the firm CSR disclosure by 0.1672 , while other variables remaining constant. This implies that ID has a significant positive impact with the CSR disclosure.

Similarly the control variable ROA, reported a positive significant contraction with CSR reporting of the Sri Lankan banking, finance and insurance companies $(t=2.20$ and $p<0.05)$ and this conformed to the positive coefficient of 0.0061

Firm size shows a positive and significant association with the level of CSR disclosure. This can be justified with a positive $(t=6.39$ and $p<0.01)$ and confirmed by the positive coefficient of 0.1433 . This is consistent with previous research (Ho \& Wong, 2001; Rouf, 2011; Khan et al., 2013; Muttakin et al., 2015; Hackston \& Milne, 1996; Haniffa \& Cooke, 2005; Michelon \& Parbonetti, 2012) and points to the likelihood that larger companies give more attention to managing their stakeholders and have strategies to increase CSRD.

The rest of the other corporate governance variables, female board members $(t=-0.25$ and $p>0.05)$, and audit committee size $(t=0.96$ and $p>$ $0.05)$ did not significantly impact on CSR.

\section{Hypotheses Testing}

$\mathrm{H}_{1}$ a is not supported as indicated in Table 5 with a $p$ value of 0.067 which is higher than 0.05 . The finding complies with previews studies (Said et al., 2009; Rouf \& Harun, 2011). It clearly shows that CSR activities do not need big board size.

The $\mathrm{H}_{1} \mathrm{~b}$ is not supported because the $p$ value is 0.802 , this is greater than 0.05 . This indicates that there is no significant impact of women board members on CSR reporting. The finding express that women participation does not influence the CSR of the firm (Sadia et al., 2015; Khan, 2010). 
$\mathrm{H}_{1} \mathrm{c}$ is not supported as indicated in Table 5 with a $p$ value of 0.341 which is higher than 0.05 . It can be concluded that the size of the audit committee does not have any significant impact on CSR. The finding complies with previous studies (António, 2017).

The proportion of the independent directors' tends to push for more CSR and it reduces the agency cost of the firm (Jensen \& Meckling, 1976). This study found a positive significant impact of board independence on CSR ( $\mathrm{t}=2.18$, coef $=.1672, p=0.031$ ). This is consistent with prior findings (Petra, 2005; Barako \& Brown, 2008; Rao et al., 2012). Our results thus imply that the greater the board independence, the more likely that companies will emphasize on societal interests and organizational legitimacy (Haniffa \& Cooke, 2005) and disclose more CSR activities, supporting $\mathrm{H}_{1}$ d. Our results also support the notion that independent directors can put pressure on companies to engage in CSR to ensure congruence between organizational actions and societal values or organizational legitimacy.

Table 6: Summary of the Hypotheses Tested

\begin{tabular}{ccccc}
\hline $\begin{array}{c}\text { Hypotheses } \\
\text { No }\end{array}$ & $\begin{array}{c}\text { Relationship } \\
\text { between two } \\
\text { variables }\end{array}$ & Relationship & Results & Outcome \\
\hline $\mathrm{H}_{1} \mathrm{a}$ & BS and CSR & Not significant & $\mathrm{P}>0.05$ & Not Supported \\
\hline $\mathrm{H}_{1} \mathrm{~b}$ & WOB and CSR & Not significant & $\mathrm{P}>0.05$ & Not Supported \\
\hline $\mathrm{H}_{1} \mathrm{c}$ & SAC and CSR & Not significant & $\mathrm{P}>0.05$ & Not Supported \\
\hline $\mathrm{H}_{1} \mathrm{~d}$ & ID and CSR & Significant Positive & $\mathrm{P}<0.05$ & Supported \\
\hline Source: Survey data & & & &
\end{tabular}

\section{CONCLUSION}

This study examined the impact of corporate governance practices on corporate social responsibility in listed Sri Lankan banking, finance and insurance companies. The annual data over the period from 2013 to 2017 were collected from annual reports of the selected companies which was available at the CSE's web site. The study covered ten banks, seven finance companies and three insurance company listed in the Colombo stock exchange. Descriptive statistic, correlation analysis and multiple regression analysis were used to estimate the result. The major findings of the study are summarized below: 
Independent directors, return on assets and firm size has a significant impact on corporate social responsibility. But other corporate governance practices namely board size, women on board and size of audit committee have not significantly influenced on the corporate social responsibility. Therefore the selected banking, finance and insurance companies' board size, women participation and size of audit committee size did not affect corporate social responsibility of the firms. It may de determined by the other factors.

\section{REFERENCES}

Abeysekera, I. (2010). The influence of board size on intellectual capital disclosure by Kenyan listed firms. Journal of Intellectual Capital, 11(4), 504-518.

AbuRaya, R. K. (2012). The relationship between corporate governance and environmental disclosure: The UK evidence. PhD Thesis, Durham University.

Achua, J. K. (2008). Corporate social responsibility in Nigerian banking system. Society and Business Review, 3(1), 57-71.

Adams, R., \& Ferreira, D. (2009). Women in the boardroom and their impact on governance and performance. Journal of Financial Economics 94(2), 291-309.

Ahern, K. R., \& Dittmar, A. K. (2012). The changing of the boards: The impact on firm valuation of mandated female board representation. Quarterly Journal of Economics, 127(1), 137-197.

Allegrini, M., \& Greco, G. (2011). Corporate boards, audit committees and voluntary disclosure: Evidence from Italian listed companies. Journal of Management and Governance, 15(3), 1-30.

Arcay, M., \& Vazquez, M. (2005). Corporate characteristics, governance rules and the extent of voluntary disclosure in Spain. Advances in Accounting, 21(1), 299-331. 
Arora, P., \& Dharwadkar, R. (2011). Corporate governance and corporate social responsibility (CSR): The moderating roles of attainment discrepancy and organization slack. Corporate Governance International Journal of Business, 19(1), 136-152.

Baker, M., \& Wurgler, J. (2004). A catering theory of dividends. The Journal of Finance, $\operatorname{LIX}(3), 1125-1165$.

Barako, D., \& Brown, A. (2008). Corporate social reporting and board representation evidence from the Kenyan banking sector. Journal of Management and Governance, 12(4), 309-324.

Barnett, M. (2007). Stakeholder influence capacity and the variability of financial returns to corporate social responsibility. Academy of Management Review, 32(3),794-816.

Bedard, J., \& Gendron, Y. (2010). Strengthening the financial reporting system: Can audit committees deliver? International Journal of Auditing, 14(2), 174-210.

Best Practice on Corporate Governance, Colombo. The Securities and Exchange Commission of Sri Lanka \& the Institute of Chartered Accountants of Sri Lanka. Available: http:// www.sec.gov.lk, 23-7-2012.

Bhimani, A., \& Soonawalla, K. (2005). The corporate responsibilities continuum. Journal of Accounting and Public Policy, 24(3), 165-174.

Botosan, C. A. (1997). Disclosure level and the cost of equity capital. The Accounting Review, 72(3), 323-349.

Campbell, K., \& Mníguez-Vera, A. (2008). Gender diversity in the boardroom and firm financial performance. Journal of Business Ethics, 83(3), 435-451.

Carter, D. A., Simskins, B. J., Fouza, F. D., \& Simpson, W. G. (2003). The diversity of corporate board committees and firm performance. Financial Review, 35(1), 371-390. 
Cowen, S., Ferreri, L., \& Parker, L. (1987). The impact of corporate characteristics on social responsibility disclosure: A typology and frequency-based analysis. Accounting Organizations and Society, 12(1), 111-122.

Deegan, C. (2002). The legitimising effect of social and environmental disclosures - A theoretical foundation. Accounting, Auditing and Accountability Journal, 15(3), 282-311.

Dias, A., Rodrigues, L. L., \& Craig, R. (2016). Global financial crisis and corporate social responsibility disclosure. Social Responsibility Journal, 12(4), 654- 671.

Ehsan, S., \& Kaleem, D. A. (2012). An Empirical investigation of the relationship between corporate social responsibility and financial performance: Evidence from manufacturing sector of Pakistan. Journal of Basic and Applied Scientific Research, 2(3), 2909-2922.

Elzahar, H., \& Hussainey, K. (2012). Determinants of narrative risk disclosures in UK interim reports. Journal of Risk Finance, 13(2), 133-147.

Eng, L., \& Mak, Y. (2003). Corporate governance and voluntary disclosure. Journal of Accounting and Public Policy, 22(4), 325-345.

Fallah, M. A., \& Mojarrad, F. (2019). Corporate governance effects on corporate social responsibility disclosure: empirical evidence from heavy-pollution industries in Iran. Social Responsibility Journal, 15(2), 208-225.

Fama, E. F., \& Jensen, M. C. (1983). Separation of ownership and control. Journal of Law and Economics, 26(2), 301-325.

Freedman, M., \& Jaggi, B. (2005). Global warming, commitment to the Kyoto protocol, and accounting disclosures by the largest global public firms from polluting industries. The International Journal of Accounting, 40(3), 215-232. 
Freeman, R. E. (1984). Strategic Management: A Stakeholder Approach. Boston: Pitman.

Gray, R., Kouhy, R., \& Lavers, S. (1995). Corporate social and environmental reporting: A review of the literature and a longitudinal study of UK disclosure. Accounting, Auditing \& Accountability Journal, 8(2), 47-77.

Gul, F., \& Leung, S. (2004). Board leadership, outside directors expertise and voluntary corporate disclosures. Journal of Accounting and Public Policy, 23(2004), 351-379.

Habbash, M. (2016). Corporate governance and corporate social responsibility disclosure: Evidence from Saudi Arabia. Journal of Economic and Social Development, 3(1), 93-94.

Hackston, D., \& Milne, M. (1996). Determinants of social and environmental disclosures of New Zealand companies. Accounting, Auditing and Accountability Journal, 9(1), 77-108.

Haniffa, R., \& Cooke, T. (2005). The impact of culture and governance on corporate social Reporting. Journal of Accounting and Public Policy, 24(5), 391-430.

Ho, S., \& Wong, K. (2001). A study of the relationship between corporate governance structure and the extent of voluntary disclosure. Journal of International Accounting Auditing and Taxation, 10(2), 139-156.

Huafang, X., \& Jianguo, Y. (2007). Ownership structure, board composition and corporate voluntary disclosure: Evidence from listed companies in China. Managerial Auditing Journal, 22(6), 604-619.

Jensen, M. C., \& Meckling, W. H. (1976). Theory of the firm: Managerial behavior, agency costs and ownership structure. Journal of Financial Economics, 3(4), 305-360.

Kennedy, P. (1998). A guide to econometrics. (M. Press, Ed.) 
Khan, A., Muttakin, M. B., \& Siddiqui, J. (2013). Corporate governance and corporate social responsibility disclosures: Evidence from emerging economy. Journal of Business Ethics, 114(2), 207-223.

Khan, M. H. (2010). The effect of corporate governance elements on corporate social responsibility (CSR) reporting: Empirical evidence from private commercial banks of Bangladesh. International Journal of Law and Management, 52(2), 82-109.

Kiliç, M., Kuzey, C., \& Uyar, A. (2015). The impact of ownership and board structure on corporate social responsibility (CSR) reporting in the Turkish banking industry. Corporate Governance International Journal of Business in Society, 15(3), 357-374.

Krippendorf, K. (1980). Content analysis: An introduction to its methodology. New York: Sage.

Larrinaga, C., Archel, P., \& Fernández, M. (2008). The organizational and operational boundaries of triple bottom line reporting: A survey. Environmental Management, 41(1), 106-117.

Li, J., Mangena, M., \& Pike, R. (2012). The effect of audit committee characteristics on intellectual capital disclosure. The British Accounting Review, 44(2), 98-110.

Lindblom, C. (1994). The implications of organizational legitimacy for corporate social performance and disclosure. Paper Presented at the Critical Perspective on Accounting Conference. New York.

McWilliams, A., \& Siegel, D. (2000). Corporate social responsibility and financial performance: correlation or misspecification? Strategic Management Journal, 21(5), 603-609.

Michelon, G., \& Parbonetti, A. (2012). The effect of corporate governance on sustainability disclosure. Journal of Management and Governance, 16(3), 477-509. 
Muktar, J., Mohammad, B. S., Jibril, R. S., \& Muhammad, S. (2016). The effect of corporate governance on corporate social responsibility disclosure by firms in the Nigerian food product industry. Research Journal of Finance and Accounting, 7(13), 28-38.

Muttakin, M., Khan, A., \& Subramaniam, N. (2015). Firm characteristics, board diversity and corporate social responsibility: Evidence from Bangladesh. Pacific Accounting Review, 27(3), 353- 372.

Nazli, A., \& Ghazali, M. (2007). Ownership structure and corporate social responsibility disclosure: Some Malaysian Evidence. The International Journal of Business in Society, 7(3), 251-266.

Palazzo, G., \& Scherer, A. G. (2006). Corporate legitimacy as deliberation: A communicative framework. Journal of Business Ethics, 66(1), 71-88.

Persons, O. S. (2009). Audit committee characteristics and earlier voluntary ethics disclosure among fraud and no-fraud firms. International Journal of Disclosure and Governance, 6(4), 284-297.

Petra, S. T. (2005). Do outside independent directors strengthen corporate boards. Corporate Governance, 5(1), 55-64.

Rahman, A. H. A., \& Muhamad, S. F. (2013). Corporate governance and firms' cash holding in Malaysia. Proceeding of the International Conference on Social Science Research, ICSSR 2013. 4-5 June 2013, Penang, Malaysia. Organized by WorldConferences.net.

Rao, K. K., Tilt, C. A., \& Lester, L. H. (2012). Corporate governance and environmental reporting: An Australian study. Corporate Governance, 12(2), 143-163.

Rizk, R., Dixon, R., \& Woodhead, A. (2008). Corporate social and environmental reporting: A survey of disclosure practices in Egypt. Social Responsibility Journal, 4(3), 306-323.

Rouf, M. (2011). The relationship between corporate governance and value of the firm in developing countries: Evidence from Bangladesh. International Journal of Applied Economics and Finance, 5(3), 237-244. 
Sadia, M., Tariq, A., \& Saba, S. (2015). The effect of corporate governance elements on corporate social responsibility disclosure: An empirical evidence from listed companies at KSE Pakistan. International Journal of Financial Studies, 3(4), 530-556.

Said, R., Zainuddin, Y. H., \& Haron, H. (2009). The relationship between corporate social responsibility disclosure and corporate governance characteristics in Malaysian public listed companies. Social Responsibility Journal, 5(2), 212-226.

Shen, J., \& Benson, J. (2016). When CSR is a social norm: How socially responsible human resource management affects employee work behavior. Journal of Management, 42(6), 1723-1746.

Siregar, S. V., \& Bachtiar, Y. (2010). Corporate social reporting: Empirical evidence from Indonesia Stock Exchange. International Journal of Islamic and Middle Eastern Finance and Management, 3(3), 241-252.

Van der Laan Smith, J., Adhikari, A., \& Tondkar, R. H. (2005). Exploring differences in social disclosures internationally: A stakeholder perspective. Journal of Accounting and Public Policy, 24(2), 123-151.

Wai, W. Y. (2013). The effect of corporate governance on cash holdings: Evidence from Hong Kong (Doctoral dissertation, Hong Kong Baptist University Hong Kong).

Webb, E. (2004). An examination of socially responsible firms' board structure. Journal of Management and Governance, 8(3), 255-277.

Zahra, S. A., \& Pearce, J. A. (1989). Boards of directors and corporate financial performance: A review and integrative model. Journal of Management, 15(2) 291-334.

Zahra, S., \& Stanton, W. (1998). The implications of board of director's composition for corporate strategy and performance. International Journal of Management, 5(2), 229-236. 